\title{
The subject of sovereignty. Law, politics and moral reasoning in Hugo Grotius*
}

\section{Annabel Brett, Cambridge}

\section{Introduction}

The genealogical turn taken by much of the best recent scholarship in the history of political thought has brought with it a new interest in the way that Hugo Grotius thinks about sovereign power. In The sleeping sovereign, Richard Tuck argues that the conceptual move critical to the modern idea of sovereignty is the distinction between sovereignty and administration or government, a distinction that Bodin and Hobbes make but that Grotius does not. Heir to the scholastics in this respect, Grotius does not have a modern theory of sovereignty. ${ }^{1}$ A different perspective is offered by Quentin Skinner, for whom the scholastic language of summa potestas, supreme power, does form part of the genealogy of modern sovereignty. ${ }^{2}$ In his most recent From humanism to Hobbes, Skinner develops his view to focus on the subject of sovereign power, the civitas or "state." He suggests that a theory of state sovereignty, as opposed to popular sovereignty, connects Grotius with Hobbes. ${ }^{3}$ Skinner's view contrasts, in turn, with that of Daniel Lee, who argues, in Popular sovereignty in early modern constitutional thought, that Grotius's appeal to the Roman law of property allows him to maintain a kind of popular sovereignty (in the sense that the people remains "free") under monarchy except for the case of the patrimonial kingdom. ${ }^{4}$

\footnotetext{
* This paper was originally written for the workshop "Hugo Grotius's place in the history of moral and political philosophy" (KU Leuven, April 2017). I am grateful to all those present for their perceptive and stimulating comments, and likewise to subsequent audiences at Vanderbilt, London and Cambridge. My thanks in particular to the editors of $M I H$, especially Darrin McMahon, and to the two reviewers for $M I H$, from whose exceptionally acute and learned reports this paper has benefited enormously.

${ }^{1}$ Richard Tuck, The Sleeping Sovereign. The Invention of Modern Democracy (Cambridge, 2016), 6386. Kinch Hoekstra considers the distinction in Bodin and Hobbes compared to early modern authors other than Grotius in "Early modern constitutionalism and absolutism," 34 Cardozo Law Review 1079. See further the exchange between Tuck and Hoekstra in Annabel Brett and James Tully with Holly Hamilton-Bleakley, eds., Rethinking the Foundations of Modern Political Thought (Cambridge, 2006): R. Tuck, "Hobbes and democracy," 171-190 and K. Hoekstra, "A lion in the house: Hobbes on democracy," 191-218. For Bodin in particular, see now Sophie Nicholls, "Sovereignty and government in Jean Bodin's Six Livres de la République (1576)," Journal of the History of Ideas (forthcoming).

${ }^{2}$ Quentin Skinner, "A genealogy of sovereignty," in Hent Kalmo and Quentin Skinner eds., Sovereignty in Fragments. The Past and Future of a Contested Concept (Cambridge, 2010), 26-46.

${ }^{3}$ Quentin Skinner, From Humanism to Hobbes (Cambridge, 2018), 42-43.

${ }^{4}$ Daniel Lee, Popular Sovereignty in Early Modern Constitutional Thought (Oxford, 2016), 255-271. For a thorough-going recent reconsideration of the idea popular sovereignty, see Richard Bourke and Quentin Skinner eds., Popular Sovereignty in Historical Perspective (Cambridge, 2016).
} 
In my own previous treatment of the subject, I suggested that Grotius's theory was uneasily caught between two different models of the political "body" - the civitas and the populus, or "people" - and consequently between two different models of political power, scholastic potestas and Hobbesian imperium. ${ }^{5}$ I now think, however, that the fluidity with which Grotius moves between these terms is in fact a marker of a new understanding of civitas in The Law of War and Peace, and correspondingly of a new conception of the international political order. ${ }^{6}$ In the present contribution, I develop that perspective by revisiting his theory of sovereignty in the light of the recent literature. I begin, however, not with sovereignty but with the kind of reasoning Grotius deems appropriate to handling it. I argue that Grotius's mature jurisprudence, in respect of both natural and positive law, is supplemented and conditioned by a broader set of principles that he calls "morals." This field of reasoning has debts to scholastic moral theology, giving the continuity with scholastic thought identified by Tuck and others, but it also has its roots in Aristotelian moral science as understood by Grotius's contemporaries. To unearth that context is to reveal again the importance of Aristotle and Aristotelian commentary to early modern thought on sovereignty, including the Roman exemplum, which historians such as Noah Dauber, Kinch Hoekstra, Melissa Lane and Sophie Smith as well as Tuck have lately done so much to make visible. ${ }^{7}$ Approaching the question from this angle, I argue in a second move that Grotius's anti-Bodinian argument for temporary and divisible sovereignty is distinctively his own insofar as it represents a modulation between law and "morals." I suggest, moreover, that precisely this modulation allows him both to separate his own scientific jurisprudence from the science of politics, in a way that he argues Bodin has failed to do, and nevertheless to reply to the political scientists on their own turf.

\footnotetext{
${ }^{5}$ Annabel S. Brett, Changes of State. Nature and the Limits of the City in Early Modern Political Thought (Princeton, 2011), 134-38; more generally in "Political thought," in Hamish Scott, ed., The Oxford Handbook of Early Modern Europe (Oxford, 2015), Vol. II, 29-55, at 35-6.

${ }^{6}$ See Annabel Brett, "The space of politics and the space of war in Hugo Grotius's De iure belli ac pacis," Global Intellectual History 1 (2016), 33-60, at 41. I argue that Grotius's terminology for the political body is fluid between gens ("nation"), populus ("people"), civitas ("political community"), respublica ("commonwealth") and ultimately exercitus ("army"). There is some aspectival difference involved, but it takes all of them together to capture the nature of the entity he is talking about.

${ }^{7}$ See, in addition to the works already cited, Noah Dauber, State and Commonwealth. The Theory of the State in Early Modern England, 1549-1640 (Princeton, 2016); Kinch Hoekstra, "Athenian democracy and popular tyranny," in Bourke and Skinner, eds., Popular Sovereignty, 15-51; Melissa Lane, "Popular sovereignty as control of office-holders: Aristotle on Greek democracy," ibid. 52-72; Sophie Smith, "Democracy and the body politic from Aristotle to Hobbes," Political Theory 46/2 (2016), 167-196.
} 
However much, then, Grotius was indebted to the scholastic account of summa potestas - and he surely was - his conception of sovereignty is shaped by a different intellectual enterprise and cannot easily be assimilated either to the scholastic or indeed to any other early modern account. But that enterprise is not merely one of putting political scientists and Bodinian confusion in their place. Grotius's theory of sovereignty in The Law of War and Peace was articulated in and for a context that he perceived as primarily international - or, better, interpolitical, referring to the concept of "interpolity" developed by Lauren Benton and her colleagues to characterize the fluid legal regimes of the early modern imperial world: a complex web of cross-state relationships that defy the modern contrast between the international and the domestic. ${ }^{8}$ I suggest that, for him, interpolity in this sense is not merely actual, in a way that theories like Bodin's fail to recognize, but normative, insofar as its willing embrace of overlap and hybridity is a facilitator of peace; and I argue that the mobilization of "morals" is critical to its realization.

Establishing the framework necessary for inter-political peace comes, however, with a key consequence for what we might think of as "domestic" politics, one that is not merely incidental but central to its conceptual construction. It is that sovereignty in exercise has no necessary location in the people that are the object of its power. It can be exercised by anyone or anything that is capable of so doing, from inside or outside the commonwealth, provided that they have been legitimately instituted in some way. ${ }^{9}$ The functional conception of sovereignty that Anne Orford sees behind the modern international law doctrine of "responsibility to protect" makes an illuminating comparison. On her account, it is this conception that allows protection to be taken over by international bodies such as the UN, or by other nations on international authority, should the sovereign of a particular nation fail to exercise it. The result is an "international executive rule" that is politically disempowering for the very people whose need for protection provides the justification for international intervention. ${ }^{10}$ One might put the point more generally by saying that a functional conception of sovereignty is inherently anti-

\footnotetext{
${ }^{8}$ See Lauren Benton, "Possessing empire. Iberian claims and interpolity law," in Saliha Belmessous ed., Native Claims. Indigenous Law against Empire, 1500-1920 (Oxford, 2011), 19-40; Lauren Benton and Adam Clulow, "Empire and protection: Making interpolity law in the early modern world," Journal of Global History 12/1 (2017), 74-92; Benton and Clulow, "Legal encounters and the origins of global law," in Jerry H. Bentley, Sanjay Subrahmanyam and Merry Wiesner-Hanks, eds., The Cambridge World History, Volume 6, Part 2 (Cambridge, 2015), 80-100.

${ }^{9}$ The point is underlined in Tuck, Sleeping Sovereign, 84.

${ }^{10}$ Anne Orford, International Authority and the Responsibility to Protect (Cambridge, 2011), 1-41, quotation at p. 32 .
} 
democratic in the sense that it is not necessarily democratic. In Tuck's genealogy, which is not merely one of modern sovereignty but of modern democracy, the point about indivisible and permanent sovereignty is that, ultimately, it turns the people into the sovereign. Sacrifice indivisibility and permanence for functionality and you remove, on this account, the foundations upon which modern democracy is built.

It is not the purpose of this article to rescue Grotius from democratic critique by suggesting that he was, in spite of appearances, some kind of democrat or theorist of popular sovereignty. In my view, he very clearly was not. Nor am I trying to place him somewhere on the spectrum of modernity. In a genealogy of international executive rule, Grotian sovereignty appears just as "modern" as in a genealogy of democracy it does not. Instead, what I shall hope to show is that Grotian sovereignty resists this either/or. It deliberately defies the Bodinian conception of domestic sovereignty, and it challenges the ideological invocation of "the people" that pulls modern democracies towards forms of national populism. At the same time, however, it equally challenges the political evasions through which functionalist international regimes absolve themselves from direct democratic accountability. In a world of profound tension and even polarity between the two, Grotius's inter-political alternative is still worth thinking through.

\section{1. - "Morals"}

In passing, throughout The Law of War and Peace, Grotius makes reference to a category of "morals" (moralia, materia moralis - "moral things," "moral matters"). The casual way in which he uses this language implies that his reader will immediately know what he means. And indeed, there were two obvious points of reference for a moderately well-educated reader of the early seventeenth century. One was Aristotelian ethics in contemporary Latin philosophical commentary, where the Greek term ethica was translated into a vocabulary of moralia or simply mores. The other was scholastic moral theology, to which Grotius paid his respects in the preface by conceding that, for all their deficiencies, "when they [the scholastics] agree on a matter of morals (in re morum), they are almost never wrong." 11 These theologians were Aristotelians too, in their way. But neither they nor the philosophers were slavish adherents to everything Aristotle said, and both interpreted him in ways that are often at odds with modern

\footnotetext{
${ }^{11}$ Hugo Grotius, De iure belli ac pacis (henceforth IBP), ed. Jean Barbeyrac (Amsterdam, 1720), Prolegomena, n. 52. I have used this edition for ease of collation with the readily available eighteenthcentury English translation which is edited by Richard Tuck as The Rights of War and Peace (Indianapolis 2005), although all translations here are my own. The Barbeyrac edition is not always accurate, and I have from time to time signaled a divergence from editions overseen by Grotius.
} 
views of "Aristotelianism". ${ }^{12}$ Appreciating the complex triangulation between scholastic casuistry, Aristotelian philosophy and Aristotle himself is vital to understanding the question of "morals" in Grotius's thought. It is not the same question as whether he was or was not an ethical eudaemonist or moral realist. ${ }^{13}$ This is not to say that there is no relationship between virtue and "morals" in his thought; there is, as I shall hint at the end of Section IV. But for a better appreciation of his enterprise, we need to start by distinguishing between the two. ${ }^{14}$

In the scholastic moral theology of Grotius's time, the basic sense of the "moral" was established through a contrast with the "natural."15 This in turn involved a further contrast, between freedom and necessity. Natural things are necessitated, as ice necessarily melts in the sun, for example. But moral things are a function of the human will, which is free. For example, whether you pay your rent or not is freely chosen and therefore a moral rather than a natural action. This does not mean that there is no concept of necessity in morals, but it is moral necessity, not natural necessity. Moral necessity is generated by the "end," the final cause, which does not operate physically but morally, in making something the only morally possible choice for the will (even though, consistently with free-will, it remains naturally free to do

\footnotetext{
${ }^{12}$ I make this point at greater length in "The Matter, Forme, and Power of a Common-Wealth": Thomas Hobbes and late renaissance commentary on Aristotle's Politics', Hobbes Studies 23 (2010), 72-102.

${ }^{13}$ See, for example, Tobias Schaffner, "The eudaemonist ethics of Hugo Grotius (1583-1648): Premodern moral philosophy for the $21^{\text {st }}$ century," Jurisprudence $7 / 3$ (2016), 478-522; on the opposing side, Benjamin Straumann, "Adam Smith's unfinished Grotius business, Grotius's novel turn to ancient law, and the genealogical fallacy," Grotiana 38 (2017), 211-228, and Richard Tuck, "The 'modern' theory of natural law," in Anthony Pagden ed., The Languages of Political Thought in Early Modern Europe (Cambridge, 1987), 99-119.

${ }_{14}$ Thomas Mautner, "From virtue to morality. Antoine le Grand (1629-199) and the new moral philosophy," Jahrbuch für Recht und Ethik 8 (2000), 209-232, rightly distinguishes between "morality" and virtue ethics but suggests too sharp a contrast between the two in Grotius, foreshadowing Pufendorf. For the interplay between law and virtue in Grotius see Sarah Mortimer, "Law, justice and charity in a divided Christendom, 1500-1625," in Paolo Amorosa, Mónica Rovira-García Salmones and Martti Koskenniemi eds., International Law and Religion: Historical and Contemporary Perspectives (Oxford, 2017), 25-42, at 34-40. An important recent article that also foregrounds the language of the moral in Grotius's thought, though from a different perspective, is Stefanie Ertz, "Hugo Grotius's hermeneutics of natural and divine law," Grotiana 37 (2016), 61-94, and see now also Martti Koskenniemi, "Imagining the rule of law. Rereading the Grotian tradition," European Journal of International Law, forthcoming.

${ }^{15}$ See Annabel Brett, "Human freedom and Jesuit moral theology," in Martin van Gelderen and Quentin Skinner eds., Freedom and the Construction of Europe, Volume 2 (Cambridge, 2012), 9-26; Dennis Des Chene, Physiologia: Natural Philosophy in Late Aristotelian and Cartesian Thought (Ithaca and London, 1996), 168-211; Michael J. Murray, 'Pre-Leibnizian moral necessity', The Leibniz Review 14 (2004), 1-64.
} 
something else). Importantly for our purposes, however, "morality" does not apply to actions alone. It also involves a range of moral entities that are created by precisely this (moral) action of the (free) will. For example, your obligation to pay the rent is a moral entity caused by your free will determining itself to a certain contractual arrangement. Moral entities also all include laws, rights, powers, offices, statuses, prices and signs - in fact, all of what we would call the social and political world and its institutions; and moral theology is, accordingly, the governing science of that world.

Grotius's debt to this tradition was recognized close to his own time - Leibniz, for example, counted him "among the most eminent" of the casuists. ${ }^{16}$ We can now see, however, that moral theology in the kinds of people Grotius was reading did not reduce to the casuistry of individual obligation that it later became, thereby earning a bad name for itself. ${ }^{17}$ For a writer like the Jesuit Francisco Suárez, casuistry does not merely say what law a subject can safely disobey in certain circumstances; it governs what counts as law itself. The astonishing political confidence of that voice was recognized by its adversaries in England, from Alberico Gentili who commanded the theologians to "keep silence" to Sir Francis Bacon who derided Suárez as "a daring and confident writer, a fellow that thinks with his magistrality and quill-pen to give laws and menages unto crowns and sceptres." 18 But for Grotius, who (as we shall see) read Suárez's The Laws and God the Lawgiver very soon after it came out in 1612, that confidence was something he could use: scholastic "morals" provided a way to establish the contours of law in circumstances beyond the domain of civil law and of technical legal reasoning. Thus, concerning the natural right to self-preservation, Grotius deployed the concept of moral necessity to argue that someone who has the right to the end must also have a right to the means. ${ }^{19}$ Equally, concerning the obligations of travelers, he borrowed from Suárez to argue that "for the government of a people it is morally necessary that those who mingle with them even only temporarily, as happens when they enter the territory, should render themselves conformable to the institutions of that people." ${ }^{20}$ Both of these examples fall outside the strict

\footnotetext{
${ }^{16}$ Theodicy, § 182; I owe the reference to Mautner, "From virtue to morality," 231.

${ }^{17}$ See the discussion in Jennifer Pitts, Boundaries of the International. Law and Empire (Cambridge MA, 2018), 79-81.

${ }^{18}$ Alberico Gentili, De iure belli libri tres, ed. T.E. Holland (Oxford 1927), I. 12, p. 55; Francis Bacon, The charge against William Talbot in The Works of Lord Bacon, in two volumes, with an introductory essay (London: William Ball, 1838), p. 688, col.1.

${ }^{19}$ IBP III.1.2.1.

${ }^{20}$ IBP II.2.5. I discuss this example further in Brett, "The space of politics," 43.
} 
scope of domestic law, and, in both, moral reasoning is used to establish legal norms that apply to all persons in such circumstances.

The salience of circumstance was a general principle that connected scholastic casuistry with Aristotelian moral philosophy in a broadly humanist vein. ${ }^{21}$ In Book I of the Nicomachean Ethics, Aristotle had contrasted ethical science with mathematics on grounds of the variability of the phenomena it studies. An educated person, he suggested, will not expect the same degree of precision in all areas of enquiry. ${ }^{22}$ Alberico Gentili had invoked this principle in support of his own enterprise of theorizing international jurisprudence at the opening of De iure belli (1598). ${ }^{23}$ Grotius, in his chapter on doubtful causes of war in Book II, enthusiastically agreed. "What Aristotle says is very true, that in morals certainty cannot be found equally as in the mathematical disciplines." Whereas mathematical phenomena abstract from all matter, in morals even the least "circumstances" alter the matter; and, whereas mathematical forms have no "in-between" (there is nothing in between curved and straight, for example), moral forms have an extensive "in-between", such that they can tend now to one extreme and now to the other. ${ }^{24}$ Grotius invoked a related principle in his discussion of what counts as a legitimate political community (civitas) under the law of war. Against Cicero, Grotius insisted that lapses from strict justice do not automatically disqualify a civitas, because "in morals (in moralibus), the principal [that is, as Grotius clarifies, the predominant element in the mix] is taken for the form." ${ }^{25}$ Another key international legal norm, then, is here shown to be established by appeal to "morals."

Despite this broad area of agreement, Aristotelian philosophers needed to address the technical method of moral science in a way that the casuists, for whom it was subsumed under theology, did not. Aristotle's elliptical remarks in Nicomachean Ethics Book I about arguing to first principles or from first principles were the subject of intense debate in the late sixteenth century between the Paduan philosopher Jacopo Zabarella and the Sienese Francesco Piccolomini. ${ }^{26}$

\footnotetext{
${ }^{21}$ See Margaret Sampson, "Laxity and liberty in seventeenth-century English political thought," in E. Leites ed., Conscience and Casuistry in Early-Modern Europe (Cambridge, 1988), 72-118, at 78.

${ }^{22}$ Aristotle, Nicomachean Ethics, ed. and tr. R. Crisp (Cambridge, 2000), Book I, Ch. 3, 4-5.

${ }^{23}$ Gentili, De iure belli, I.1, p. 10.

${ }^{24}$ IBP II.23.1-2. This chapter explicitly juxtaposes the most up-to-date humanist Aristotelian scholarship with scholastic moral theology.

${ }^{25}$ IBP III.3.2.1-3.

${ }^{26}$ See David A. Lines, Aristotle's Ethics in the Italian Renaissance (ca. 1300-1650). The Universities and the Problem of Moral Education (Leiden, 2002), Ch. 7. The passage in question is Nicomachean Ethics, Book I, Ch. 4, p. 6 (tr. Crisp): "Let us not forget, however, that there is a difference between arguments from first principles and arguments to first principles... For, while we should begin from
} 
Zabarella had argued that in the practical sciences, including ethics, not only the method of investigation, but also the order of presentation, must be "resolutive" (or "analytic") rather than "compositive" (or "synthetic"). "Resolution" involves tracking back to first principles, from effect to cause; "composition" the reverse, tracking forward from the principles, from cause to effect. Piccolomini had agreed that this was Aristotle's order of investigation in the Nicomachean Ethics, but had denied that the order of presentation must always be "resolutive." Instead, in his highly original and influential Universa philosophia de moribus, he adopted a "compositive" order, forward from the nature of man to the nature of commonwealth itself. ${ }^{27}$ The work was well-known to Gentili, who referred to it at the very start of his De iure belli in distinguishing contemporary moral and political philosophy from his own enterprise as a jurist of the law of nations. ${ }^{28}$ Grotius himself cited it in Book II, Chapter 23, the chapter on doubtful causes that we have just looked at. ${ }^{29}$

Subsequent commentators largely agreed on the resolutive as opposed to the compositive approach to both investigation and presentation, a distinction that was also near-universally framed in terms of a posteriori versus a priori. But they disagreed on what the relevant effects and causes were. Grotius's fellow Dutchman, Hubert van Giffen (Giphanius), was one of the most acute of all Renaissance commentators on both the Ethics and the Politics, cited in Gronovius's notes to The law of war and peace although not by Grotius himself. In his commentary on the Ethics, published posthumously in 1608, van Giffen argued that the principles we seek are not causes at all, but explanations. He kept the language of "effects," however, arguing that these are human actions themselves. In moral science, then, we track back from the actions to what explains them, which are the principles of natural law. ${ }^{30}$

things known, they are known in two senses: known by us, and known without qualification. Presumably we have to begin from things known by us... For the first principle is the belief that something is the case, and if this is sufficiently clear, he will not need the reason why as well."

${ }^{27}$ Francesco Piccolomini, Universa philosophia de moribus (Venice, 1583), Introductio, Cap. 21-24, 31-32.

${ }^{28}$ Gentili, De iure belli, I.1, at 1 .

${ }^{29}$ Grotius's citation in fact dates back to his earlier De iure praedae, Ch. 7, p. 124 in M. van Ittersum ed., Commentary on the Law of Prize and Booty (Indianapolis, 2006). The marginal reference in both cases is to Piccolomini's "Civil Philosophy Lib. VI, cap. XXI," i.e. Universa philosophia de moribus, Gradus VI, cap. 21, fol. 354. The reference to "Civil Philosophy" is explained by the fact that, for Piccolomini, moral philosophy just is civil philosophy, and his headings reflect this fact. See below, p. 000 .

${ }^{30}$ Obertus Giphanius (Hubert van Giffen), Commentarii in decem libros Aristotelis ethicorum ad Nicomachum (Frankfurt, 1608), Lib. I, Cap. 4, p. 29. 
Zabarella's German student Johannes Magirus, author of a more popular textbook called the Corona virtutum moralium ("A crown of moral virtues," 1614), argued more standardly that resolution proceeds from effects to causes. For him, the effects are the virtuous actions that we see around us, and we track back to their causes, which are the virtues themselves. ${ }^{31}$

Grotius appealed to the "resolutive" procedure in a key passage of Book I, to support his argument that the dictator in ancient Rome was genuinely a sovereign and not merely some kind of minister. Given, he suggested, that the dictator exercised all the functions of sovereignty, he was sovereign; the temporary duration of his sovereignty did not affect its nature as such. This argument was clearly directed against Bodin. ${ }^{32}$ What has received less comment, however, is the "moral" reasoning behind it: "the nature of moral things is known from their works (operationes), which is why those faculties that have the same effects, are to be called by the same name." ${ }^{33}$ Here, we track back from the effects to the causes, just as in Aristotelian moral science. But we do not do so in exactly the same way as in the commentators we have looked at, since sovereign power is neither a virtue nor a principle of natural law. Instead, as we shall see in more detail in the next section, it is a "moral faculty," a moral entity, and we discern it by distinguishing between works (operationes) and actions (actiones). Again, then, Grotius fused Aristotelian moral science with scholastic moral theology to answer a question that Alberico Gentili, in his key chapter on international intervention, had insisted could not be a purely "domestic" issue: what power counts as sovereign power. ${ }^{34}$

\section{2. - Moral, legal and political science}

So far we have seen how Grotius used a hybrid concept of "morals" to solve questions of law in international contexts. But it is still not clear quite how he understood the nature of the interface between legal and moral reasoning. Both scholastic and humanist Aristotelians would have seen the science of law, properly understood, as continuous with the field of morals. For the scholastics, as we have seen, law was a key effect of the operation of the free will and thus a central part of moral theology. For the humanist commentators on Aristotle, the matter was a bit more complicated because it was not clear that Aristotle had a science of law, in the sense of a jurisprudence, at all. He had nomothetike, the science of legislation, and he had dikastike,

\footnotetext{
${ }^{31}$ Ioannes Magirus, Corona virtutum moralium (Frankfurt, 1614), pp. 30-32.

${ }^{32}$ See Tuck, Sleeping Sovereign, 23-5 (for Bodin), 70-83 (for Grotius).

${ }^{33}$ IBP I.3.11.2: rerum moralium natura ex operationibus cognoscitur, quare quae facultates eosdem effectus habent, eodem nomine nuncupandae sunt.

${ }^{34}$ Gentili, De iure belli, I.16.
} 
the art of judgement, but neither of these seemed quite to accommodate what van Giffen recognized as a distinctively Roman idea. Nevertheless, both Piccolomini and van Giffen found a place for it in relation to nomothetike $\bar{e}$, the more universal and philosophical side of political science as laid down by Aristotle in Nicomachean Ethics Book VI, Ch. 8. ${ }^{35}$ Differently from the commentators, however, Grotius's intellectual enterprise did not require him to find an Aristotelian solution at all costs. He made this plain in the preface, acknowledging Aristotle as the first of philosophers but refusing to agree with him on everything, in particular his notorious argument that every virtue is a mean between excess and deficiency. ${ }^{36}$ Inept for all the virtues, this principle was peculiarly deficient for justice and for its object, the iustum ("what is right" or "the right thing").

Grotius had, in fact, argued against the Aristotelian conception of justice from the very beginning of his natural jurisprudence, The Law of Prize of 1604/5. Here, he set out instead to arrive at "what is right" in a totally different way, joining a raging sixteenth- and seventeenthcentury debate about how to make law into a science (ius in artem redigendum) ${ }^{37}$ For Grotius this meant going back to "the fount of nature," ad fontem naturae. ${ }^{38}$ In the preface to The Law of War and Peace, Grotius again stressed the importance of science (ars), and as in The Law of Prize, too, he grounded his effort in nature. He declared that naturalia, natural things, can be made into a science (ars) because they are certain and invariable. The implicit contrast is with moralia, those imprecise and circumstantially varying phenomena that are the object of Aristotelian moral science and scholastic moral theology. ${ }^{39}$ In a key move, however, he borrowed from Suárez's scholastic opponent Gabriel Vázquez in taking natural law out of the operation of the free will, even God's. Instead, natural law is simply what is necessarily fitting or unfitting to rational nature - or, as Grotius crucially added a little further on, rational and

\footnotetext{
${ }^{35}$ Piccolomini, Universa philosophia, Gradus V, cap. 38, fo. 293-4; van Giffen, In libros ethicorum, Lib. VI, cap. 8, p. 489. See further below, p. 000 and 000.

${ }^{36}$ IBP, Prolegomena, nn. 40-45.

${ }^{37}$ For an overview, including Grotius, see James Gordley, The Jurists: A Critical History (Oxford, 2013), 111-140. Benjamin Straumann, Roman Law in the State of Nature. The Classical Foundations of Hugo Grotius's Natural Law (Cambridge, 2015), 103-129, stresses the anti-Aristotelianism.

${ }^{38}$ van Ittersum ed., Commentary, Ch. 1, p. 17. The Latin text can be found in Hugo Grotius, De jure praedae commentarius, 2 vols. (Oxford 1950), Vol. II: Collotype reproduction of the original Latin manuscript.

${ }^{39}$ IBP, Prolegomena, n. 30. For naturalia as contrasted with the products of human free will, see Straumann, Roman Law, 45-6, and for the a priori argument, ibid., 66-70.
} 
social nature. ${ }^{40}$ As a result, it can be demonstrated not only a posteriori, like Aristotelian moral science, but a priori.

Grotius used the same conception of naturally social human nature to define "what is right," the iustum. ${ }^{41}$ In a piece of similar a priori reasoning, he argued that the iustum is what is not repugnant to a society of those who use reason. He then, however, made a move that we do find in Suárez and indeed in most of the scholastics, which is to argue over from "what is right" objectively to the rights that are held subjectively by individuals. He called this kind of right a "moral quality." 42 I think it is arguable that this is in itself a "resolutive" move: that is, from what is not repugnant to human society we track back to the rights to do those actions. Just as for the scholastics, these rights are moral entities (in this case, moral qualities), and as such they are subject to moral reasoning, as we saw above with the right to the means of selfpreservation. But, and this is a big but, they have through the iustum a hard a priori edge in consistency or inconsistency with natural human society. This hard edge serves to restrict the category of individual rights to "perfect" rights, by which he meant those faculties that are the object of what the scholastics called "commutative," what Grotius called "rectificatory," justice. ${ }^{43}$ They are spaces of dominium in which the individual's will is the determining factor. Rights in the sense of claims of merit, the object of distributive justice, are not properly rights. This hard a priori edge in a scientific, independently identifiable nature distinguishes Grotius's natural jurisprudence from Alberico Gentili's, for whom the appeal to nature is an element of our shared moral rhetoric. ${ }^{44}$ But a priori reasoning is inadequate by itself to cope with the rights

\footnotetext{
${ }^{40}$ IBP I.1.10.1; I.1.12.1, convenientia aut disconvenientia cum natura rationali ac sociali. Appreciating the importance of this addition, Barbeyrac inserted the words "and social" (ac sociali) into the first of the two passages as well. The debt to Vázquez is probably via Suárez's own discussion of natural law, though Grotius elsewhere referred to him directly. For the discontinuity in Gabriel Vázquez between ius naturale and all other forms of law (lex), see Annabel Brett, "Later scholastic philosophy of law," in Fred D. Miller and Carrie-Ann Biondi eds., A Treatise of Legal Philosophy and General Jurisprudence, Volume 6: A History of the Philosophy of Law from the Ancient Greeks to the Scholastics (Dordrecht, 2015), 335-375, at 361-2.

${ }^{41}$ IBP I.1.3.1.

${ }^{42}$ IBP I.1.4.

${ }^{43}$ The continuity between the scholastic and the Grotian concept of rights is underlined in Martti Koskenniemi, "International law and the emergence of mercantile capitalism: Grotius to Smith," in Vincent Chetail and Peter Haggenmacher eds., The Roots of International Law (Leiden, 2013), 1-37. ${ }^{44}$ Alberico Gentili, De iure belli, I.1, citing Aristotle's Rhetoric. On the close connection between moral and rhetorical argument in the Renaissance see Eckhard Kessler, "The method of moral philosophy in Renaissance humanism," in David A. Lines and Sabrina Ebbersmeyer eds., Rethinking Virtue,
} 
that individuals actually have. Purely a priori, all individuals have rights to do anything not incompatible with human society. But, of course, as a matter of fact they do not. They have particular sets of rights that are the results of multiple historical contractual arrangements. We shall see at the end how important this was to his "moral" way of thinking. Nevertheless, granted the individual's will is the determinant of rights, the question immediately arises of how we are to interpret that will, given that it is invisible in itself. In his key chapter "On interpretation," Grotius argued that there must be some general procedural rules in order to avoid a collapse into pure subjectivity of meaning. Such a collapse would mean that the matter could never be decided, "which is reputed impossible in moral matters." To avoid it, in a context of inevitable obscurity, we have to use "the most probable signs," of which there are two types, words and conjectures, and there are rules governing how these are to be interpreted. ${ }^{45}$ It is here, rather than in the appeal to nature, that Grotius finds space for the rhetorical dimension of moral reasoning.

By reworking the scholastic distinction between "morals" and "naturals" through the concept of a naturally social human nature and consequent "perfect" rights, Grotius was able to construct an interface between moral and legal science that allowed for a complex back-andforth between the two kinds of reasoning. By contrast, Grotius saw a much more straightforward distinction between legal science and the science of politics, and here he again departed from his Aristotelian philosopher contemporaries. Politics, for them, was a practical science, and thus shaped by the same kind of "moral" reasoning as ethics. Moreover, influential voices in the humanist Aristotelian tradition commenting on Nicomachean Ethics Book I, in which Aristotle declares that his enquiry in this work is politike tis, a kind of civil science, had denied any sharp difference between ethics and politics. For Piccolomini, a "universal philosophy of morals" was precisely the same as "civil philosophy." Likewise for van Giffen, ethics just is politics: ethics has no independent identity in Aristotle's scheme of the various arts and sciences. ${ }^{46}$ Both of them were prepared to see some kind of differentiation between the theoretical and the practical aspects of "political science" in this all-encompassing sense, so that the Ethics contains the principles and the Politics the practice. Following Aristotle

Reforming Society. New Directions in Renaissance Ethics, c. 1350 - c. 1650 (Turnhout, 2013), 107129.

${ }^{45}$ IBP II.16.1.1-2. See Quentin Skinner, Forensic Shakespeare (Oxford, 2014), esp. 226-268, for the operation of conjecture in forensic rhetoric.

${ }^{46}$ Piccolomini, Universa philosophia, Introductio, cap. 11, fo. 14; van Giffen, In libros ethicorum, Lib. I, cap. 2, and Lib. VI, cap. 8, p. 491. 
himself in Nicomachean Ethics Book VI, Chapter 8, they made a distinction between the universal or "architectonic" (architektonikē) science of passing laws (nomothetikē) and the science of particular political actions, this latter being commonly called politike or politics itself. ${ }^{47}$ Piccolomini explained that such activity is specifically called "politics" not because of its dignity, but because of its use (usus), which is visible to the people. ${ }^{48}$ From a scientific point of view, however, both van Giffen and Piccolomini were clear that political science includes both moral science and jurisprudence.

Grotius, however, deliberately resisted any attempt to "theorize" political science in this way. For him, Aristotle's unqualified merit was to have written a work of Politics that was purely about politics. He drew a contrast with Jean Bodin, whose work, he declared, had mixed up politics and jurisprudence. For Grotius, political science (ars politica) teaches quid ex usu sit facere, "what needs to be done on the basis of use." He thus apparently positioned as the entirety of political science the usus that Piccolomini had characterized as simply the most mundane and vulgarly obvious part of it. On this basis Grotius was able to contrast jurisprudence, which does handle principles, with politics, which does not, a contrast that he also (albeit briefly) framed in terms of the distinction between the useful (utile) and the right (iustum). ${ }^{49}$ As the case of sovereignty shows, however, the "resolutive" approach that characterizes moral reasoning allowed him to take the effective reality of a political situation into account whilst still claiming to offer a legal rather than a political analysis. Indeed, as we shall see, for Grotius political science was not properly analytic at all.

\section{3. - Resolving sovereignty}

Grotius tackled the issue of sovereignty in Chapter III of Book I, which concerns who has the power to declare war. Political power (potestas civilis), he began, is "the moral faculty of governing the political community" (facultas moralis gubernandi civitatem). ${ }^{50} \mathrm{It}$ is, then, another case of a moral entity, to which moral reasoning can apply. What does this power consist in? "Aristotle sets up three parts in administering the commonwealth, deliberation on

\footnotetext{
${ }^{47}$ Van Giffen, In libros ethicorum, Lib. VI, cap. 8; Piccolomini, Universa philosophia, Gradus V, cap. 37.

${ }^{48}$ Piccolomini, ibid. fo. 292 and Introductio, cap. 11, fo. 14.

${ }^{49}$ IBP, Prolegomena, n. 57.

${ }^{50}$ IBP I.3.6.1.
} 
common affairs, the responsibility to select magistrates, and legal judgements." ${ }^{11}$ In starting with this reference to Aristotle, Grotius departed from the scholastics to begin his tacit critical engagement with Bodin, for this is the passage that Bodin in his Method for the Easy Comprehension of History (first edition 1566) had used in order to criticize Aristotle for not conceptualizing sovereignty properly (and hence, given that for Bodin the commonwealth depends on sovereign power, not having an adequate politics at all). Bodin's objection was that Aristotle had treated all of these on a par, whereas, in Bodin's view, deliberation and judgement can belong to non-sovereigns, with only the appointment of magistrates a distinctively sovereign power. ${ }^{52}$

Grotius did not directly engage with this critique. But he implicitly agreed that Aristotle's political analysis of "three parts" in the Politics needed correcting, and he proceeded to do so by means of Aristotle's bipartite distinctions in Ethics VI. As we have seen, Aristotle there distinguished within political science between architektonike (nomothetikē) and politikē more commonly so-called. He then specified that the latter consists in bouleutike (concerned with deliberation or counsel) and dikastike (concerned with judicial matters). Grotius translated this into series of dichotomies of his own. Thus, he said, a ruler's activity takes place either by himself (or itself) or by means of others; by himself, is either in respect of universal matters or in respect of particular matters; such particular matters can be either public or private. Architektonike is legislative science and is universal. Politike is particular and is equivalent to bouleutike in being concerned with particular matters that are directly public, e.g. war and peace, making treaties, taxation. Finally, dikastike or "judicial science" is concerned with particular matters that are private but nevertheless of public interest. Surprisingly, however, given that he had specifically mentioned the appointment of magistrates, Grotius did not

\footnotetext{
${ }^{51}$ In the 1625,1631 and 1646 editions, Grotius's reference is consistently to Politics IV.4. In Barbeyrac's edition the citation is tacitly corrected, I think rightly, to Politics IV.14, the opening of which makes precisely this tripartite distinction. It should be noted, however, vis-à-vis the second "part," that Aristotle refers to the nature and competencies of magistrates as well as the responsibility to select them. Grotius's focus specifically on the appointment of magistrates is itself an index of the Bodinian background.

52 Jean Bodin, Method for the Easy Comprehension of History, tr. Beatrice Reynolds (New York, 1969), Book VI, at 155-157; discussed in Tuck, Sleeping Sovereign, 17-18, and Lane, "Popular sovereignty as control of office-holders," 68-9. Lane argues that Bodin only gradually came to put legislation as the first mark of sovereignty.
} 
concern himself with it; he merely remarked that what the ruler does not do by him- or itself, he/it does through others, who are magistrates or other officials, including ambassadors. ${ }^{53}$

Grotius was not the first to read the tripartite distinction in the Politics in the light of Aristotle's two dichotomies in the Ethics. Van Giffen, in his commentary on the latter, also crossreferenced the two, and his moves make an interesting comparison. Using the terminology of Senatus (counsel or deliberation, bouleutikē), Magistratus (magistracy in general, not specifically the appointment of magistrates) and Iudicium (judgement) for Aristotle's three parts, he argued that Aristotle's primary distinction in both works was in fact bipartite: between a properly ruling, i.e. sovereign, element and an administrative element. In the Ethics commentary, he put Magistratus alone as administrative (administer). In the Politics commentary, by contrast, both judges and magistrates are administrative (administri), and only Senatus is sovereign (Aristotle's kurion, which van Giffen translated princeps). Senatus is here said to include legislation, the right of war and peace, the appointment of magistrates and in fact all the other things that Bodin called the "marks" of sovereignty ${ }^{54}$ In a less complicated way, the English Aristotelian John Case had also interpreted the Ethics VI passage in terms of a bipartite distinction between "that which makes laws" and "that which is popularly called executive." $" 55$

In the light of this we can see that, although Grotius had begun by quoting Aristotle as if there were no distinction at all between sovereign and administrative functions ("Aristotle sets up three parts in administering the commonwealth"), in fact his first dichotomy (a ruler's activity takes place either by him- or itself or by means of others) reflects a distinction between the two forms of political activity that had already been made by other commentators. But Tuck is nevertheless right to suggest that he did not then try to define sovereign power as a particular kind of power within the (revised) Aristotelian mix. ${ }^{56}$ In this he differed sharply from van Giffen, whose strategy was designed to defeat Bodin on his own ground at the price of accepting the Bodinian definition of sovereignty. Grotius, in contrast, kept Aristotle's three elements from Nicomachean Ethics VI (not Politics IV) on a par as different but equal functions of civil power, not seeing the "universal" element of law-making as any more a sovereign

\footnotetext{
${ }^{53}$ IBP I.3.6.1.

${ }^{54}$ van Giffen, In libros ethicorum, Lib. VI, cap. 8, p. 490; Obertus Giphanius, Commentarii in politicorum opus Aristotelis (Frankfurt, 1608), Lib. IV, cap. 14, pp. 490-493, 500.

${ }_{55}$ John Case, Speculum moralium quaestionum (Frankfurt, 1589), p. 426. For Case in the context of Elizabethan politics, see Dauber, State and Commonwealth, Ch. 3.

${ }^{56}$ Tuck, Sleeping Sovereign, p. 85.
} 
activity than the "particular" activities of deliberation or judgement. Sovereign power is just this tripartite civil power with summitas - highest-ness, subjection to none - layered on top (addita summitate). ${ }^{57}$

The position that Grotius adopted in The Law of War and Peace comes into relief in comparison with his earlier works. In The Law of Prize, following the account in Chapter 2 of the genesis of the commonwealth from the natural society of mankind, we find a series of marginal headings that echo some of the "parts" of Politics IV.14. The first is Respublica et cives, the commonwealth and the citizens; then comes Iudicium, and then Magistratus. "Law properlyspeaking" (Lex proprie dicta) comes under Respublica et cives, as "the will of the universi [the citizens as forming one body] directed towards the universi." Iudicium is instead "the will of the universi directed towards individuals, in the light of the public good." Finally, Magistratus is linked directly with the necessity of administration. In this sequence, then, law-making and judgement are both sovereign functions of the Respublica et cives, with magistracy the administrative, non-sovereign function. Grotius made this clear by asserting (with a marginal reference to the Dominican scholastic Francisco de Vitoria) that "civil power, which is seen in laws and judgements, is primarily and per se in the commonwealth (respublica) itself." That this power is sovereign power is clear a little further on, with the declaration that "above (supra) the commonwealth, which is a multitude sufficient in itself, there is no greater power (imperium)." ${ }^{58}$ In The Law of Prize, then, Grotius accepted the Bodinian position on lawmaking as a distinctively sovereign power. His inclusion of judgement as an equally sovereign power, however, was another marker of his debt to the scholastics, who did not draw a sharp line between the supreme power to legislate and supreme jurisdiction in the sense of not recognizing a superior. ${ }^{59}$

Grotius developed his thought on sovereignty in De imperio summarum potestatum circa sacra, composed between 1614 and 1617. Here, his concern to argue the power of the sovereign over religious affairs led him to stress both the unity of the sovereign ruler and the universality

${ }^{57}$ IBP I.3.7.1; addita summitate is at IBP I.3.17. Grotius here glossed summitas with the Greek term to anupeuthunon, "unaccountability." For this terminology in Grotius and other early modern writers, see Hoekstra, "Athenian democracy and popular tyranny," at 6-8.

${ }^{58}$ van Ittersum ed., The Law of Prize, Ch. 2, pp. 36-44; Collotype reproduction, fo. 10'-12, 13.

${ }^{59}$ See, for example, the Jesuit Luis de Molina in his De iustitia et iure (Mainz, 1614, first published 1593-1600), Tract. V, Disp. 2 and 3, who argues for a broad definition of supreme jurisdiction that includes legislation, appointing public officials, and other functions. Likewise, Francisco Suárez saw supreme power as convertible with supreme jurisdiction: Francisco Suárez, De legibus ac Deo legislatore, ed. Luciano Pereña Vicente (Madrid, 1968-72), III. 1. 8-9. 
of sovereign power. ${ }^{60} \mathrm{He}$ argued for the necessary unity of the sovereign through a resolutive procedure, much like that in The Law of War and Peace, back from the "effects" to the "powers and faculties" that cause them. The effects of sovereignty are obligation and coercion: were the power to be divided between plural sovereigns, a subject could potentially be obliged to two things simultaneously. But such an effect is impossible, hence sovereign power cannot be divided. In a case of apparent division of sovereignty between king and estates, the real situation, Grotius asserted, is that either the estates alone are sovereign, or the "body" of both king and estates together is sovereign. Thus, there is always only one sovereign, and its sovereign power is accordingly universal, not limited to a particular domain. With a reference to Aristotle, Grotius characterised the "science of ruling" (ars regnandi) involved in sovereignty as architektonike - not as contrasted with politike, however, but rather as a universal science that embraces all the others. ${ }^{61}$

In De imperio, then, Grotius espoused a Bodinian thesis on unity. Strikingly, this appears to be in direct contrast to the position on divisibility that he had espoused in his defence of the Dutch Revolt, the Commentarius in Theses XI (of uncertain date but almost certainly later in the same decade as The Law of Prize) ${ }^{62}$ It is not clear, however, that Grotius in either work saw a conflict between scholastic thought on summa potestas and Bodin's thesis of indivisibility, both of which he endorsed at the level of the power itself. In De imperio, he supported his position on the king-and-estates scenario with a reference not only to Bodin but to Vitoria and to the Jesuit Francisco Suárez, whose The Laws and God the Lawgiver had been published in $1612 .{ }^{63}$ The references to Bodin and Vitoria are already there in the Commentarius. ${ }^{64}$ Nevertheless, there is

\footnotetext{
${ }^{60}$ Hugo Grotius, De imperio summarum potestatum circa sacra, ed. Harm-Jan van Dam (Leiden, 2001), Vol. I, Ch. I, pp. 160-162. The importance of this work in the development of Grotius's thought has recently been reasserted by Ertz, "Hugo Grotius's hermeneutics," at 63, 77-86.

${ }^{61}$ The term architektonike here is linked with quotations from Plato and Philo, the effect of which is to suggest that this is not the specific architektonike of Nicomachean Ethics Book VI, but is a reference to Aristotle's use of the term in Book I, in which politike or political science in general is characterised as architektonike in respect of all others.

${ }^{62}$ Ertz, "Hugo Grotius's hermeneutics," 85.

${ }^{63}$ The reference to Suárez is almost certainly to his handling of the question whether the acceptance of the people is necessary to make law. Suárez argued that this was only the case in a strict democracy. In any other form of constitution, the necessity to involve the estates does not represent a sharing of sovereign power between the king and the people; rather, it is the king and the estates together which form the sovereign: De legibus, Lib. III, q. 19, n. 6.

${ }^{64}$ Commentarius in Theses XI, tr. P. Burton, in Peter Borschberg ed., Hugo Grotius' "Commentarius in Theses XI." An early treatise on sovereignty, the just war, and the legitimacy of the Dutch revolt (Bern, 1994), at 228-9. I share the translator's slight unease ("Foreword," 205) with the translation of actus
} 
undoubtedly a difference in emphasis between the two works. De imperio is concerned to articulate a unitary and all-embracing sovereign power. The Commentarius equally posits the existence of this power, but is more concerned to articulate instead the possibility of dividing its "acts" or functions (actus).

As Peter Borschberg has noted, the similarity between the Commentarius and The Law of War and Peace in this respect is very striking. ${ }^{65}$ Both of these works are more concerned with legal distributions of power that cross between states than with the power of a single state, whether vis-à-vis its internal constituents or vis-à-vis an external enemy: the inter-political rather than the strictly political. The Commentarius addresses the complex political relationship between Spain and the Low Countries at the time of the Dutch Revolt, a relationship, on Grotius's account, which Spain aggressively violated and to which the Dutch were forced to respond not merely by vindicating their share of the actus, but by vindicating their sovereign power itself. The Law of War and Peace rehearses all the historic inter-political relationships of the Commentarius, and imagines more. However, the position on power and function (actus) that supports divisibility in the Commentarius falls foul of the resolutive demand of De imperio, according to which we judge powers from effects. Divided functions or "acts" imply, precisely, divided powers. Grotius in The Law of War and Peace therefore needed some way in which to block a resolution that went as far back as dividing the sovereign power of the commonwealth, and thus dividing the commonwealth itself. He achieved this through his famous split-level analysis, not of the nature, but of the location of sovereign power.

Returning to Book I, Chapter III, then, after defining sovereign power Grotius proceeded to the contentious question of its location. Here he made his key distinction between the "common subject," which is the civitas, and the "proper subject," which is the ruler. ${ }^{66}$ This distinction has some antecedents in scholastic thought. On the scholastic account, political power is an allembracing power for the preservation and well-being of the political community. It originates at the moment of the formation of that community, and rests at that moment in the community as a whole. In order to be exercised effectively, however, it needs to be transferred, on the community's terms, to a ruler or rulers who are different from the community itself. But in

\footnotetext{
summae potestatis as "marks of sovereignty," preferring his alternative "functions," although I entirely concur with the editor about the engagement with Bodin. The reference to Vitoria is given as De potestate civili, n. 14.

${ }^{65}$ See his critical study in Borschberg ed., "Commentarius in Theses XI," 129-135.

${ }^{66}$ IBP I.3.7.1.
} 
cases of outright tyranny on their part, it devolves in some way back down to the community. ${ }^{67}$ The community is thus the default holder of political power - but not sovereign power, which, for the scholastics, was always the power of the ruler. But Grotius was unwilling to abandon his original and constant position, developed in the context of the Dutch Revolt and of the ensuing war with Portugal and Spain, that the civitas is in some way the subject of sovereign power. In The Law of War and Peace, his solution was to make the civitas the "common subject" of sovereignty through an analogy between the moral faculty of governing and the natural faculty of sight. Sight, as a faculty of the soul, is located in the eye as the "proper subject." Its "common subject," however, is the whole body, which is vivified by the soul of which the faculty of sight is a part. ${ }^{68}$ It is this that constitutes the historic political identity of the civitas as a nation or a people: a living body of human beings that exists in time and place, that can be exiled, and can settle again. ${ }^{69}$

For all that Grotius undoubtedly borrowed from the scholastics, then, his conception of the common subject is not a direct debt to their thought. It is the result of a demand for a "resolution" of sovereignty for which they had no conceptual need. As said at the outset, however, it comes with the key political consequence that sovereignty as actually exercised has no necessary location in the people (populus) that it governs. Grotius spelled this out explicitly, allowing even total alienation of power, in the manner of a person engaging to be the slave of a master, as a possibility (although not a necessity: Grotius's sense of the contingency of the location of sovereign power was a further debt to the scholastics). He continued in the following section with a series of attacks on the sacred cows of popular sovereignty, for example that the constituent is necessarily greater than the constituted, or that the king is for the sake of the kingdom. Neither of these, he argued, is necessarily the case (although he did concede that it is often the case). He had, moreover, a sharp remark to make on the appeal to "the people" made by "popular" states, i.e. republics. There is no state so popular, he argues, that it does not exclude from the people "the very poor, or strangers, women

\footnotetext{
${ }^{67}$ A classic account is given in Quentin Skinner, Foundations of Modern Political Thought (Cambridge, 1978), Volume 2, Part 2; commentary in Annabel Brett, "Scholastic political thought and the modern concept of the state," in Brett and Tully eds., Rethinking the Foundations, 130-148, esp.137-40.

${ }^{68}$ The question of the localization of the soul in the body was discussed by both humanist and scholastic philosophers commenting on Aristotle's De anima. The closest I have found to Grotius here is Jacopo Zabarella in his Liber de partitione animae, in De rebus naturalibus libri XXX (Frankfurt, 1607), Cap. 14 , arguing that the faculty of sight is originaliter (by way of origin) in the whole body which is the location of the entire soul, but in the eye alone subiective (in terms of its subject).

${ }^{69}$ Brett, Changes of State, pp. 134-138, 199-200; “The space of politics,” pp. 36-42.
} 
and adolescents." 70 Contrary to contemporary theories of popular sovereignty, for Grotius the exclusion of these people from "the people" is a constitutional matter. However popular the state, the exclusions that all popular states involve in fact make them less popular.

\section{4. - Dividing sovereignty}

Given that sovereign power does not have to be located in the people as its proper subject, the question now arises of how we are to diagnose its location in different constitutional arrangements. Here Grotius continued his implicit engagement with Bodin, who had argued that sovereignty must be both perpetual and undivided, ruling out any kind of "mixed constitution." In the case of the Roman republic, the first condition meant that, although the dictator who was appointed in times of crisis appeared to have sovereign power, he in fact did not because his power was only temporary. The second meant that the Greek historian of Rome, Polybius, was wrong in his famous analysis of the Roman republic as a mixed constitution. It was in fact a democracy, in which the people was sovereign. Grotius in The Law of War and Peace differed profoundly because, as we have seen, he allowed that the Roman dictator was sovereign. He also differed on the second point, in that he allowed sovereignty to be divided. But this is not because he did not make any distinction in this work between sovereignty and administration; he did, and in fact he agreed with Bodin that Polybius was wrong about the Roman republic. We need, therefore, to look more closely at what he says about the Roman example.

We have already seen how Grotius argued for the sovereignty of the dictator using "moral" resolution. ${ }^{71}$ A little further on he separated his mode of analysis from that of "people writing politics" (politica scribentes) like Polybius, who, looking only at the actions (actiones) and not the right of acting (ius agendi), i.e. looking only at "the external form and the day-to-day administration" (externa species et quotidiana administratio), had diagnosed in the Roman republic a mixed constitution - whereas in fact sovereignty (summum imperium) lay with the people and it was therefore a popular state. ${ }^{72}$ Here, then, is the distinction Grotius made in the preface between political science and jurisprudence, associated with a contrast between daily administration and sovereignty, external form and moral nature. A slightly different phrase occurs in a passage a little earlier on, where Grotius warns his readers not to be deceived by

\footnotetext{
${ }^{70}$ I.3.8.6. Grotius in 1625 listed only the first three, so in subsequent editions his sense of exclusion deepened to include adolescents.

${ }^{71}$ IBP I.3.11.1, cf. I.3.8.12.

${ }^{72}$ IBP I.3.19.
} 
the ambiguous sound of a name and the species externarum rerum, "form of external things." The Roman emperors were called principes, or "first citizens," but it would be wrong to infer from this terminology that Rome was still a republic, since they "held openly and without disguise the most absolute monarchical power." 73 This may constitute another implicit critique of Bodin, who in the Six livres (1576) (Book II, Ch. 1) had drawn a distinction between "en matiere d'estat" and "en termes de droit." "En matiere d'estat," the one who commands the force, commands the commonwealth. But "en termes de droit," this is not so. The Roman emperors were in effect sovereign monarchs, but legally they were no more than "princes," first citizens. From the point of view of the law, therefore, the Roman state remained a republic. $^{74}$

Finally, in an important passage in Book II Grotius again distinguished the viewpoint of the jurist from that of the political scientist, and again used the case of Rome. Here he argued that Rome remained the same civitas, as the same people and the same "common subject" of sovereignty, despite all the vicissitudes of its various proper subjects of sovereignty (king, people, emperor). This is the form (species) of the civitas that the jurist looks at. By contrast, the political scientist looks at the form which consists in the "relation of the parts between themselves, the rulers and the ruled." Because this changed radically at Rome, Rome did not remain the same on a political analysis. ${ }^{75}$ Although it is not completely clear that the externa species of Book I is the species of Book II that the political scientist looks at, in both books the distinction between political science and jurisprudence clearly lies in the faculty-function model that the jurist uses but the political scientist does not. The latter is able to distinguish "morally" between the actions (actiones) of "day-to-day administration" and the operationes or workings of an underlying sovereign power. In this way Grotius was able to craft a jurisprudence that could accommodate the reality of power in a political community without collapsing into reason of state. In contrast to Bodin, who defended his jurisprudential account of sovereignty at Rome against a kind of realist or de facto political science, for Grotius it is jurisprudence, not political science, which tells you that the Roman emperors were absolute monarchs rather than "first citizens" of a continuing republic. We might call it a kind of realist

\footnotetext{
${ }^{73}$ IBP I.3.10.1-3.

${ }^{74}$ This passage, in the Latin version of 1586, is discussed in Tuck, Sleeping Sovereign, 28-30, although the French version of 1576 seems to me the draw the contrast more clearly.

${ }^{75}$ IBP II.9.8.1-2.
} 
jurisprudence. On my account, it is precisely his conception of "morals" that allows him this position.

Rome, then, was not a permanent democracy; rather, the sovereignty completely changed hands. Nor was it ever a mixed constitution. But that is not because it never could have been. Grotius was as clear as he had always been that, as a global and supreme "moral faculty of governing the civitas," sovereign power is one, undivided thing despite the fact that it is made up of the "parts" we saw earlier. It can be composite and still a unity ${ }^{76}$ But, he argued, it can nevertheless be divided either in respect of its area of operation, or in respect of the subjects of that power. His example of the first was the subsequent division of Roman sovereignty such that one emperor held the west and another the east, or when three emperors ruled the empire at the same time. His example of the second was the kind of arrangement between a people and a monarch in which the people reserves certain elements of political power to itself. In such a case, both the people and the monarch are sovereign. ${ }^{77}$ So, while Bodin had insisted on only one locus of sovereignty within the commonwealth, for Grotius in The Law of War and Peace that was not a legal principle, merely a recommendation of policy. I suggest this is one of the things he meant by saying in the preface that Bodin had mixed up politics and jurisprudence. "In political matters," Grotius declared, "there is nothing completely free from inconvenience; and right is to be measured not from what seems best to this or that person, but on the will of that from whence the right arises." 78

Here, then, the theoretical possibility of dividing sovereignty is made legally workable and politically real through the jurisprudence of "perfect" rights, which, as we saw in Section 2, is key to the Grotian interface between legal and moral science. The proper subject of sovereign power is not just a subject but a holder of it; and, if a legitimate holder, will hold it by right. Running sovereignty through the matrix of rights in this way gave Grotius huge analytic power in addressing the contemporary state of Europe, because the extreme contingency inherent in "perfect" rights allowed for its complicated history. Importantly for his political purposes, it enabled him to defend the sovereign power of a variety of princes whose status as true sovereigns might otherwise seem questionable. We have already seen, with the case of the dictator, how moral reasoning vindicates his sovereign right, even if it is temporary. Grotius appealed to Roman legal forms to add two further ways of holding the right of sovereignty: as

\footnotetext{
${ }^{76}$ IBP I.3.17.1.

${ }^{77}$ See above, p. 000, for the contrast with De imperio, in which this scenario is not a case of division.

${ }^{78}$ IBP I.3.17.2.
} 
full property, or as a usufruct. ${ }^{79}$ For him, all these forms are equally "perfect" rights, and any perfect right can be defended in law, or by war if there is no superior judge (as a fortiori is the case if we are talking about sovereignty). Usufruct or temporary right are not positions of being in some way "inferior" to the proprietor, that is, not "superior" or not sovereign. Grotius argued that this is only so if the right is "precarious," meaning that it can be revoked at any time by the granter. But he distinguished usufruct and temporary right from precarious right in this sense. ${ }^{80}$ Certainly, a monarch with usufruct and not property in the sovereignty could not alienate it or damage its integrity in any other way. But, presuming she did neither of those, and presuming she did not share the sovereignty with any other party, her exercise of sovereign power was as absolute as that of the "patrimonial" king next door.

More importantly from a conceptual point of view, the equality of "perfect" rights offered Grotius a way to theorize the complicated inter-political situations characteristic of early modern Europe (for example the vexed question of the constitution of the Holy Roman Empire, or the situation between Spain and the Low Countries prior to the Dutch Revolt) without recourse to any notion of hierarchy or vertical ordering. Division between proper subjects of sovereignty, whether within one political community or across two (or more), is instead horizontal, in terms of different rights to exercise different functions of sovereignty. Precisely his hard-edged rights, then, supply the possibility of much more "soft-edged" inter-political arrangements. Moreover, his frank acceptance of "inconvenience" meant that he did not have to design any further features of the constitutional relationship that a more idealizing mode of theory would demand. In comparison with other attempts to defend the possibility of mixed constitution against Bodin, the Grotian rights-based model has the advantage of being almost infinitely flexible. ${ }^{81}$ It offers the possibility of quite fine-grained division without falling into theoretical incoherence; and, despite the ever-present possibility of "inconvenience," Grotius

\footnotetext{
${ }^{79}$ IBP I.3.11.1-3.

${ }^{80}$ On this point I must therefore disagree with Lee, Popular sovereignty, pp. 270-71, who argues that for Grotius a right of usufruct in the sovereignty is a precarious right, consistent with the liberty of the people. For the distinction, see Hoekstra, "Early modern absolutism and constitutionalism," 1082 n. 9, who points out that Hobbes effectively eliminates it. See also Tuck, Sleeping Sovereign, 90-91, for the vulnerability of the crowned heads of Europe on the Hobbesian (and, more tactfully, the Bodinian) accounts.

${ }^{81}$ See Hoekstra, "Early modern absolutism and constitutionalism," 1085-1090, for alternatives in Althusius, Arnisaeus and Besold.
} 
clearly felt that such arrangements were not only workable in practice but in many cases desirable.

One place to see this is in his handling of the law of war in Book III. In his chapter "Moderation in obtaining imperium" (meaning both empire in our sense and sovereignty), Grotius accepted that the law of war allows a conquering nation to wipe out the sovereignty of the vanquished entirely, and therefore to destroy it as a civitas with its own political identity. But he argued that this was almost always a bad thing to do, both in terms of virtue and in terms of policy. Ideally, the conquered should be left in full possession of their sovereignty. However, he was also prepared to suggest compromise arrangements somewhere between political annihilation and full sovereignty, accepting that to leave a conquered nation with the latter might constitute a future threat. It was possible, he suggested, to take some part of the sovereignty while leaving the conquered with another part of it, and he referred back to his remarks in Book I on the "mixing" of sovereignty to provide the juridical foundations for such solutions. ${ }^{82}$ What we might characterize pejoratively as a practice of empire, then, Grotius saw as the kind of interpolity that was perfectly familiar from European history, and perfectly compatible with the separate identity of both nations as "common subjects" of sovereignty. ${ }^{83}$ Division here is positively valorized because it can slide around either/or questions of sovereignty that Grotius thought were just bad questions. Not only are they conceptually mal posées, they are also an opening to vice and to a cynical reason of state, rather than to virtue and good policy; in the final analysis, to war rather than to peace.

\section{Conclusion}

Over the course of this discussion we have seen how the field of "morals" and its associated reasoning operate to shape the distinctive legal and political world of The Law of War and Peace. On this analysis, sovereignty is certainly a legal phenomenon, but it cannot be isolated as such. The way that it is folded into "morals" gives Grotian sovereignty its non-Bodinian and non-Hobbesian character, and it is for this reason that Grotius's theory resists being positioned within any genealogy of modern sovereignty. But that does not mean that it is in some way "medieval," and therefore of no value of us today. Grotius was attempting to theorize it within

\footnotetext{
${ }^{82}$ IBP III.15.9. If it were too risky to leave them with any political identity, Grotius concluded, at least they could be left with what we would call their cultural identity, their customs and their ways of life. This would nevertheless wipe them out as a civitas in the true sense.

${ }^{83}$ See the references above, n. 8 .
} 
a wholly new kind of science, a jurisprudence that occupies a middle ground between a purely a priori theory of rights and law on the one hand and a concrete political science on the other. If I am right, "morals" is the master-science of that middle ground, and what Grotius did in The Law of War and Peace was to mobilize it to construct an international order that is conceptualized inter-politically rather than politically in a narrow sense

I am not suggesting that we have, in Grotius, a beautiful but forgotten solution to the current tension between popular aspirations to democratic sovereignty and the demands of international executive rule. But there is nevertheless something interesting for us about the way in which Grotius handles the question. He was addressing a very messy, from the "modern" point of view, state of Europe (but not only of Europe), with all sorts of bits and pieces of jurisdictions subject to an infinity of historic legal arrangements. Where we see fragmentation, however, Grotius saw instead the positive political phenomenon of division. To theorize this optic, he moved the either/or of sovereignty from sovereign power itself to the rights to exercise it, and argued that those rights can be of different forms and held individually by several parties at the same time. Whatever the legal arrangement, however, it remains the case on his theory that whoever holds any right to exercise any part of the sovereignty is, as such, sovereign of the very country in which the sovereign power resides as in its common subject. It is this that distinguishes it from the pure functionalism analyzed by Orford as involved in modern responsibility to protect. The UN, stepping in to protect a people when its own sovereign fails to, does not constitute itself legally sovereign of that people. But for Grotius, no such legal evasion is possible. Provided the people remains a "common subject" of sovereignty, his "moral" jurisprudence tells us that an "outside" body exercising sovereignty over them is their own sovereign, however temporary. Just as with the Roman dictator, the fact that the power is temporary does not make it any the less sovereign. In this way, Grotius's international jurisprudence is political in a way that modern international executive rule is not.

To make this point is not to set aside the hard issue of democracy and the disquieting, to our eyes, distance between the common subject and the proper subject. From this point of view, Grotian interpolity looks like nothing so much as the ancien régime and its empires, systematized and justified through the matrix of property rights. On my account, there is no denying its political conservatism in a domestic context, even if, in an "external" context - to hold on to that contrast for a moment - Grotius offered proposals for peace that were quite radical from a contemporary point of view. Even in the domestic context, however, the functional model does not always operate against the people as the "proper subject" of 
sovereignty. It allows the people to be the sovereign, as in the Roman republic, or it allows them to have a share of it, perhaps the share they can most easily exercise. A people that only acts to elect a legislature from time to time can hardly be said to be the sovereign, but it nevertheless exercises a sovereign function and is sovereign in that capacity, if not in others. Perhaps that is just how the constitution works. Finally, and from a more critical point of view, Grotius explicitly draws attention to the exclusionary nature of "the people" as the proper subject of sovereignty: the lack of fit between the political "people" and the real people of a country, which still obtains today both in theory and in practice. Modern democracies may have given the vote to women and the very poor (although the latter is in practice highly dubious), but young people below a certain age and resident aliens (ordinarily) have none, let alone migrants and refugees, who are the very poorest of the poor. For Grotius, wherever there is any "proper subject" of sovereignty, whatever its nature, some people are still, and in all respects, subject. It is another form of evasion to suggest otherwise. If his "moral" jurisprudence challenges the legal logic and rhetoric of international bodies, then, it also questions the ideology of democracy.

In the face of the current tension between exclusivist populist democracy and a purely functionalist international, Grotius's first answer might be to point to the virtue of moderation, and to the possibility of softening the antagonism - losing the either/or - through various forms of division between plural "proper subjects" of sovereignty. But he would not think it enough only to pick up the notion of divisibility with its underlying functional model, however attractive that might seem. His "political" is not purely functional all the way down; for, with the "common subject," we are not dealing with "a people" that is just a body with needs for various functions to be exercised - although it is that, as well - but a people with a historic political identity. ${ }^{84}$ The only way forward, on his model, would be simultaneously to insist on the directly political nature of international bodies and on the mutual implication of every

${ }^{84}$ This is, I think, a key difference of Grotius's theory from that of Carmen E. Pavel, Divided sovereignty. International institutions and the limits of state authority (Oxford: Oxford University Press, 2015), which makes an interesting comparison. As a pragmatic solution, she attempts something similar to Grotian division, using a "principal-agent" model (Ch. 2) for the relationship between a people and its divided sovereigns, both domestic and international (meaning international institutions). As she recognises, this means a people dividing its loyalties, but argues that this is possible if the people can be brought to think of its domestic institutions "as agents with specific purposes and functions" (p. xxvi), hence losing the tension with international institutions which are agents in just the same sense. I think that Grotius would approve the spirit of the exercise, but would think that the principal-agent model makes the political functional all the way down, thereby, effectively, de-politicising it in his terms. 
nation's historic political identity with that of every other. Grotius's theory recognizes that the creation of a new inter-political order in this way would not be easy, but that does not mean that any such attempt is condemned only to replicate the ancien régime in modern form. We might not share his "morals", but he challenges us to think about our own. 